\title{
SOCIO-PSYCHOLOGICAL ASPECTS OF WOMEN'S MOTIVATION IN BUSINESS
}

УДК 159.923

DOI https://doi.org/10.32843/26635208.2020.16.39

\section{Струкова О.В.}

аспірант каседри дисреренціальної та спеціальної психології

Одеський національний університет імені І.І. Мечникова

\author{
У статті доведено, що бізнесова діяльність \\ як складний та неперервний процес успіш- \\ ного просування суб'єкта вперед соціаль- \\ ними, професійними та адміністративними \\ сходинками з метою досягнення бажаного \\ статусу та відповідної якості життя не \\ тільки розкриває потенціали та здібності, \\ ділові якості та особистісні і просресійні \\ риси, але й висуває високі вимоги до себе, \\ власної ініціативності та самостійності. \\ Відповідно, бізнес традиційно асоціюється \\ із негативними рисами та супутніми яви- \\ щами (кар'єризм, відсутність людяності, \\ емпатії, жорстка комунікація у певному соці- \\ альному колі тощо). Сучасний соціальний \\ простір постійно ускладнюється, завдяки \\ чому подібний підхід до розуміння сутності \\ бізнесової діяльності та його основних \\ суб'єктів постійно змінюється. Входження \\ Украӥни у сучасний світовий економічний \\ та культурний простір на порядок денний \\ виводить посилення ролі жінок у суспільстві, \\ повагу до їх прагнення бути незалежними, \\ мати можливість доступу до самореаліза- \\ ції у професійній діяльності та кар'єрному \\ зростанні. \\ Показано, що жіноча ідентичність у біз- \\ несі визначається як спосіб суб'єктивної \\ організації подій, який має внутрішню \\ динамічну структуру, яка інтегрує усі під- \\ структури особистості, пов'язані з ї̈ усві- \\ домленням та переживанням себе як пред- \\ ставника певної соціальної групи, але без \\ втрати індивідуальності та неповтор- \\ ності. Самоактуалізація жінки як основа \\ іï бізнесової діяльності спирається на \\ важливі тенденції сучасного суспільства - \\ зростання суб'єктної активності людини \\ та підвищення вимогливості до прав та \\ обов'язків. Наявність жіночої специфріки у \\ нейродинамічних проявах сили та дина- \\ мічності розкривають глибинні підвалини \\ успішності жінок у бізнесі, а особливості \\ когнітивної ссрери дозволяють уникати \\ гострих кутів та перебдачати можливі \\ складнощі.
}

Ключові слова: особистість, бізнесова діяльність, мотивація, гендер, ідентичність, самореалізація

The article proves that business activity as a complex and continuous process of successful advancement of the subject on social, professional and administrative steps in order to achieve the desired status and appropriate quality of life not only reveals potentials and abilities, business qualities and personal and professional traits, but and makes high demands on himself, his own initiative and independence. Accordingly, business is traditionally associated with negative traits and accompanying phenomena (careerism, lack of humanity, empathy, harsh communication in a certain social circle, etc.). The modern social space is constantly becoming more complicated, due to which such an approach to understanding the essence of business and its main subjects is constantly changing. Ukraine's entry into the modern world economic and cultural space puts on the agenda the strengthening of the role of women in society, respect for their desire to be independent, to have access to self-realization in professional activities and career growth.

It is shown that female identity in business is defined as a way of subjective organization of events, which has an internal dynamic structure that integrates all personality structures related to her awareness and experience of herself as a representative of a certain social group, but without loss of individuality and uniqueness. Self-actualization of a woman as the basis of her business activity is based on important tendencies of modern society - increase of subjective activity of the person and increase of demand for rights and obligations.

The presence of female specificity in the neurodynamic manifestations of strength and dynamism reveal the deep foundations of women's success in business, and the features of the cognitive sphere allow to avoid sharp angles and to overcome possible difficulties.

Key words: personality, business activity, motivation, gender, identity, self-realization
Постановка проблеми. Громадська та соціальна реальність сучасного українського суспільства активно стимулює формування нових поведінкових стандартів, орієнтирів у системі соціальних та індивідуальних цінностей, активний розвиток нової потребової сфери громадян та інноваційних життєвих стратегій функціонування особистості у соціально-політичному просторі. Відповідно до викликів сьогодення проблема розвитку та розумного використання власного потенціалу, високі вимоги до себе, власної ініціативності та самостійності, в тому числі у бізнесовій діяльності, є надзвичайно затребуваними та актуальними, оскільки вони щільно пов'я- зані із подіями, що відбуваються у нашому суспільстві.

Бізнес є однією зі сфер соціального життя, що дозволяе людині розкрити власні потенціали та здібності, ділові якості та особистісні і професійні риси.

Бізнесова діяльність особистості є складним та неперервним процесом успішного просування вперед соціальними, професійними та адміністративними сходинкам 3 метою досягнення бажаного статусу та відповідної якості життя.

Подібний традиційний підхід частіше асоціювався із негативними рисами та супутніми явищами (кар'єризм, відсутність людяності, 
емпатії, жорсткої комунікації у певному соціальному колі тощо).

Сьогодні на порядку денному подібні характеристики не є актуальними, вони не забезпечують успішність особистості у бізнесі, яка прагне повністю реалізовувати свій особистісний та професійний потенціали, отримати визнання та значущість для суспільства та інших людей, в тому числі у матеріальному еквіваленті.

Таким чином, бізнес як професійна діяльність приваблює як чоловіків, так і жінок, але у суспільній свідомості успішне просування у бізнесі, управління середніми та великими підприємствами переважно пов'язане із суто чоловічим образом. Водночас входження України у сучасний світовий економічний та культурний простір призводить до посилення ролі жінок у суспільстві, до їх прагнення бути незалежними, мати можливість доступу до самореалізації у професійній діяльності та кар'єрному зростанні.

Після тривалого часу, коли психологічна наука не мала ознак статі, своєрідною моделлю зміни суспільної свідомості є потреба у психологічному обґрунтуванні особистісного, продуктивного, творчого джерела жінки як носія типових рис сучасного громадянина України. Але, попри посилення ролі жінки у суспільному житті, більшість досліджень у соціальній психології переважно здійснюється на чоловічій вибірці, інколи - на групах порівняння. Актуальність цієї проблематики диктує необхідність вивчення психологічних і соціальних особливостей жінок, а особливо жінок, успішних у підприємницькій діяльності. На наш погляд, мотивація бізнес-діяльності як провідного стратегічного напряму життєдіяльності зумовлює тип соціальної поведінки, ступінь активності, загальний стиль життя жінки.

Ось чому обрана тема $є$ актуальною та своєчасною як у практиці, так і у площині соціально-психологічного наукового дослідження.

Постановка завдання. Метою статті $€$ дослідження соціально-психологічних аспектів мотивації жінок у бізнесі.

Виклад основного матеріалу. У зарубіжній та вітчизняній психологічній науці проблема мотивів та мотивації викликає незмінний інтерес та постійні дискусії науковців щодо трактування основних понять та галузей застосування. Попри привабливість тематики та її широку представленість у науці, складність дослідження мотиваційної сфери особистості традиційно пов'язана із необхідністю розпізнавання основних механізмів ії̈ формування та системоутворюючих структурних компонентів. Оскільки вивчення мотиваційної сфери складало проблемне поле для багатьох наукових розвідок, інтереси яких інколи були протилежними, особливої наукової уваги потребує спроба узагальнення та систематизації інформаційних підходів до мотивів та мотивації.

Наукові традиції сучасної психології термін «мотив» визначають, як спонукання до діяльності або певного вибору, усвідомлену причина, яка лежить в основі здійснення вибору, тобто завжди застосовується для окреслення кола явищ та станів особистості, які стимулюють її активність.

Х. Хекхаузен [15] основним критерієм диференціації мотивів вважав їхню стійкість-нестійкість, С.Л. Рубінштейн [14] заломлював їх через традиційні форми людської активності (гра, вчення, професійна, суспільнадіяльністьтощо). Різні сучасні аспекти професійної мотивації досліджувалися С.Я. Коваль, Є.М. Макотою, Л.В. Мокроусовою, Л.Г. Почебут, А.В. Толпекіною, О.Р. Фонарьовим, О.М. Ходусовим. Зокрема, у низці досліджень професійної мотивації вчені виділяли такі основні мотиви успіху, як: прагнення до досягнення успіху, вибір власних цілей, незалежність, установка на соціальну нерівність (Л.Г. Почебут [10] та ін.). В управлінській діяльності мотивація має свою специфіку, оскільки сам керівник постає важливим компонентом цілісної системи управління будь-яким виробництвом, від його дій багато в чому залежать ефективність роботи персоналу, наявність сучасних технологій, конкурентоспроможність (Є.М. Макота [7]). Навіть такі складники, як психологічний клімат, корпоративна атмосфера, мотивація працівників на досягнення загальних цілей, підтримка молодих співробітників тощо, багато в чому залежать від того, наскільки вмотивований керівник підприємства.

Оскільки бізнесова діяльність не може бути відірвана від суспільного та політичного життя країни, на особливу увагу заслуговує класифікація мотивів за суспільною спрямованістю (Т.М. Мальковська, І.О. Панкратова, О.І. Пенькова, О.Є. Рогова). Ідеї суспільно-особистісної спрямованості мотивів досліджувалися: у контексті громадянського обов'язку, патріотизму та їх прояву у особливих та екстремальних умовах життя, коли ситуація потребує від особистості мужності, волі та жертовності (Т.М. Мальковська [8]); як невіддільний структурний компонент моральної свідомості, пов'язаний з усвідомленням власного місця у суспільстві, виробленням соціальної позиції, оволодінням певною соціальною роллю, почуттям відповідальності перед суспільством за свої дії та вчинки (О.І. Пенькова [9]); особливості структуризації соціальних мотивів, виділення зовнішньої (широкої соціальної та вузькоособистої), внутрішньої (позитивної та негативної) та далекої (дистантної, відстроченої) (І.О. Панкратова, О.Є. Рогова [12]).

Окреме місце у розумінні мотиву бізнесової діяльності займає компетентнісний підхід 
(M. Csikszentmihalyi, R. DeCharms, E. Deci, J.B. Murrey, R. White), який започатковуе дослідження особистісного компоненту у бізнесі. Так, R. DeCharms не тільки наголошував на особливій ролі первинної мотивації, яка не тільки дозволяє людині відчувати себе джерелом усіх змін, але й зміцнює почуття ії компетентності, але й виділив два типи особистостей: “самобутні», тобто активні, цілеспрямовані, самодетерміновані, здатні впливати на навколишнє середовище; «пішаки», тобто схильні до переживання безпорадності та безпомічності, психологічно залежні від інших людей [20]. Такий підхід суттєво поглиблює поняття внутрішньої мотивації та роль локусу контролю як її центрального елемента та переконливо доводить, що на формування мотивації, особливо під час виконання керівних функцій, суттєвий вплив створюють такі протилежні риси, як владність або страх відповідальності [20]. Е. Deci та R. Ryan, розвинувши екстра- та інтернальний напрям у вивченні природи мотивації, ввели поняття інтринсивної та екстринсивної мотивації, а для визначення основних соціально-психологічних чинників інтринсивної мотивації вчені розробили концепцію когнітивної оцінки та виділили базові психологічні потреби, які виявляються у інтринсивно мотивованій діяльності: потреба у відчутті власної компетентності, усвідомлення себе джерелом змін у навколишньому світі та підтримка значимих міжособистісних стосунків [21].

У психологічній науці можна виділити декілька напрямів дослідження жіноцтва: через категорії ідентичності, самоактуалізації, нейродинамічні показники, особливості когнітивної сфери та комунікативної діяльності, що суттєво впливає на особливості її функціонуванні у бізнесі.

Традиційно переважна кількість досліджень у психологічній науці присвячені дослідженню ідентичності жінок (З. Фрейд, К.-Г. Юнг).

У роботах З. Фрейда основними «фемінінними» рисами вважаються пасивність, покірливість, залежність, на відміну від чоловіків, які $€$ активними, незалежними, самодостатніми. Причому будь-які прояви активності та самодостатності у жінок 3. Фрейд вважав відхиленням у психосоціальному розвитку та порушеннями жіночої ідентичності. Прямуючи за цією логікою прагнення жінок до активності у бізнесі, бажання займатися власною справою 3. Фрейд назвав би «фалічним». Така однозначність трактування повністю заперечує специфіку жіночої мотивації у бізнесі та формує однозначний підхід до жіночого «обличчя» бізнесу.

Пізніше у аналітичній психології К.-Г. Юнга розглядалися поняття «аніма» і «анімус», як сукупність рис, властивих як чоловікам, так і жінкам, започатковуючи андрогінний початок, що також не відображає гендерної специфіки бізнесової діяльності.

Сучасний підхід до проблеми ідентичності у вітчизняній науці співпадає із нашим розумінням психологічного підґрунтя, що створює умови успішного перебування жінки у бізнесі: вона визначається як спосіб суб'єктивної організації подій, який має внутрішню динамічну структуру, яка інтегрує усі підструктури особистості, пов'язані з ї̈ усвідомленням та переживанням себе як представника певної соціальної групи, але без втрати індивідуальності та неповторності (О.Є. Гуменюк, Й. Милюска, В.М. Павленко та інші). На думку вчених, саме ідентичність дозволяє жінці, яка займається бізнесом, впорядкувати власні уявлення про спосіб життя та ефективні дії, саме ідентичність у подальшому виступає базисом у прийнятті викликів зовнішнього світу, у розумінні властивостей об'єктів та використання їх для власної користі.

Для розуміння основи успішності жінки у бізнесі необхідно усвідомити основні критерії зрілої ідентичності, до яких можна віднести: стійке уявлення, що особистість, ії характер та діяльність можуть викликати в оточуючих повагу, схвалення; усвідомлення цінності власної особистості та для інших людей; адекватна самооцінка, упевненість в собі під час високої напруги діяльності; здатність до усвідомлення можливих труднощів у бізнесі; чітка визначеність життєвої позиції; висока довірливість та товариськість; орієнтація на значущість серед інших людей.

Проблема самоактуалізації жінки як основа іiї професійної діяльності $€$ достатньо розробленою в науці та спирається на важливі тенденції сучасного суспільства - зростання суб'єктної активності людини та підвищення вимогливості до прав та обов'язків. Попри виражений інтерес до вивчення самоактуалізації, в сучасній українській психології вона є дискутивною та неоднозначною. Так, Т.В. Говорун та О.М. Кікінеджи розглядають її гендерні аспекти [3]; А.В. Фурман вивчає самоактуалізацію як основний сенс життя людини, процес її становлення як особистості та фахівця; Г.О. Балл визначає її як інтегральну, усвідомлену, цілеспрямовану діяльність, яка створює умови для повної самореалізації особистості у будь-якій сфері, в тому числі у бізнесі: самоактуалізовані суб'єкти цілісно ставляться до світу, є синергічними, вільно виходять за межі «Я» та фактично створюють умови для формування особистістю основної стратегії власного зростання [1].

Наявність жіночої специфіки у нейродинамічних проявах сили та динамічності розкривають глибинні підвалини успішності жінок у бізнесі. Так, Б.Г. Ананьєв вважає, що у жінок 
переважає здатність гальмувати власну емоційну сферу, вони легше переносять сильний біль та витриваліші в умовах монотонії, більш ефективні у роботі, яка потребує вольового напруження, що також спирається на їх гальмівні здатності.

За результатами досліджень Я.І. Шкурко, жінки характеризуються більш високим рівнем розвитку сили збудження, що суттєво впливає на перцептивні здібності як важливі складникип діяльності у сфері бізнесу [15].

Специфіка перебування жінки у бізнесі також пов'язана із особливостями її когнітивної сфери. Цей напрям недостатньо представлений у наукових розробках, але є дуже перспективним, оскільки вплив на успішність у бізнесовій діяльності особливостей мислення суттєво розкриє гендерні особливості цього боку соціального життя. Навіть нечисленні дослідження у цьому напряму доводять його значущість. Так, наприклад, досліджуючи гендерні особливості мислення, М.А. Дворящина виявила, що у жінок, на відміну від чоловіків, основні характеристики логічного мислення між собою взаємопов'язані, що впливає на аналітичну та комунікативну діяльності; крім того, жіноча психіка $€$ більш пластичною щодо реагування на різні складнощі зовнішніх обставин [4].

Особливого значення в дослідженні особливостей перебування жінки у бізнесі набуває специфіка її комунікативної сфери, оскільки вона створює як негативні, так і позитивні впливи на ефективність результатів. Так, за даними досліджень О.В. Вороніної, особливості жіночої емоційності можуть негативно впливати на ефективність її діяльності, оскільки на перший план виходить емоційна нестабільність, навіюваність та інколи залежність від групи [2]. Ці гендерні особливості потрапляють у групу ризику особливо в тому разі, коли жінка стає керівником та очолює серйозну команду. На думку Я.І. Шкурко, аналізуючи особливості комунікації жінок-керівників, не слід оцінювати їх категоріями «краще-гірше», а краще підкреслювати існування своєрідності комунікативних властивостей жінки-керівника, зумовлених психологічними особливостями статі [15]. На думку автора, саме такий підхід є прогресивним, оскільки на його основі можливо розробляти вагомі спеціальні програми підготовки керівників та ефективних менеджерів різних ланок для вітчизняного бізнесу.

Висновки 3 проведеного дослідження. Таким чином, класифікація мотивів здійснюється на основі критеріїв: стійкості-нестійкості, традиційних форм людської активності (гри, вчення, професійної, суспільної діяльності), професійної та суспільної спрямованості. В зарубіжній психології широко представлені підходи до мотивів як до потреби, спонукання.
Як показав аналіз наукових першоджерел, попри широку критеріальність проблеми мотивів та мотивації, в науці наявні певні прогалини, зокрема, відсутні гендерні аспекти цього напряму, які потребують глибоких теоретико-емпіричних досліджень. Динамічні умови сучасного бізнесу на перший план виводять риси, притаманні жінці, - гармонійне поєднання пластичності та принциповості, прагнення до самоідентичності та роботи над собою, висока емпатійність та вимогливість до оточуючих та себе. У вивченні особливостей ефективної діяльності жінок у бізнесі виділяють такі напрями: через категорії ідентичності, яка визначається як спосіб суб'єктивної організації подій, інтегрує усі підструктури особистості, пов'язані з її усвідомленням та переживанням себе як представника певної соціальної групи, але без втрати індивідуальності та неповторності; через самоактуалізацію як основу бізнесової діяльності, яка спирається на зростання суб'єктної активності людини та підвищення вимогливості до прав та обов'язків; нейродинамічні показники індивідуальної поведінки (сили та динамічності нервової системи, гнучкості психіки); особливості когнітивної та комунікативної діяльності.

\section{ЛІТЕРАТУРА:}

1. Балл Г.А. Психология в рациогуманистической перспективе. Киев, 2006. 408 с.

2. Воронина О.В. Сравнительный анализ психологических особенностей женщин, ориентированных и неориентированных на участие в управлении. Жінки України: сучасний статус і перспективи. Міжнародна наук.-практ. конференція. Одеса, червень 1995. C. 261-264.

3. Говорун Т.В., Кікінеджі О.М. Стать та сексуальність: психологічний ракурс. Тернопіль, 1999. 367 с.

4. Дворящина М.А. Некоторые результаты экспериментального исследования интеллектуальных характеристик взрослого человека с учетом возрастно-половых и индивидуальных психологических характеристик. Человек и общество. 2013. Вып. 8. C. $145-150$.

5. Ильин Е.П. Мотивы и мотивация. Санкт-Петербург, 2014. 512 с.

6. Ковалев В.И. Мотивационная сфрера личности как проявление совокупности общественных отношений. Психологический журнал. 1984. Т. 5. № 4. C. 3-13.

7. Макота Е.М. Особенности мотивации трудовой деятельности современных руководителей. Мир культуры, образования и науки. 2012. Выпуск 4 (35). C. 245 .

8. Мальковская Т.Н Социальная активность старшеклассников. Москва, 1988. 140с.

9. Пенькова О.І. Психологічні аспекти моральної спрямованості особистості. /l Міжнародна науково-практична конференція «Генеза буття особиcmocmi». 2011, Toм I. С. 293-297. 
10. Почебут Л.Г. Организационная социальная психология. СПб, 2002. 298 с.

11. Реан А.А. Психология личности. Социализация, поведение, общение СПб, 2004. 416 с.

12. Рогова Е.Е., Панкратова И.А. Взаимосвязь профессиональных представлений и трудовой мотивации педагогов дошкольных образовательных учреждений. Интернет-журнал «Мир науки». 2016, Tом 4, номер 6 http://mir-nauki.com/PDF/20PSMN616. pdf (дата звернення 12.08.2020).

13. Рубинштейн С.Л. Проблемы общей психологии. Москва, 1989. 487с.

14. Хекхаузен.Х. Мотивация и деятельность Санкт-Петербург, 2003. 860 с.

15. Шкурко Я.І. Психологічні особливості управлінської діяльності жінок-керівників закладів освіти. Наука і освіта. 1998, № 4-5. С. 86-88.

16. Apter M. J. Faulty towers: A reversal theory analysis of a popular television comedy series. J. of Pop. Culture. 1982. V. 16. P. 128-138.
17. Allport G.W. Trend in Motivations Theory. Am Journal of Ortopsychiatry. 1953. V. 23. P. 38-51.

18. Atkinson J.W. An Introduction to Motivation. N.Y., 1965. P. 350.

19. Csikszentmihalyi M. Beyond Boredom and Anxiety: Experiencing Flow in Work and Play, 25th Anniversary Edition (Jossey-Bass, 2000), p. xix.

20. DeCharms R. Enhancing motivation: chang in the classroom. New York, 1976.

21. Deci E., Ryan R. Intrinsic Motivation and SelfDetermination in Human Behavior. New York - London : Plenum Press. 1985. 371 c.

22. Guilford J.P., Guilford R.B. An Analysis of the Factors in a Typical Test of Introversion Extraversion. J. of Abnormal and Social Psychology, 1934, v. 70, № 10, P. 1-26.

23. Hill A. Extraversion and variety seeking in a monotonous task Brit. J. Psychol., 1975, v. 66, p. 9-13.

24. Murrey J.B. Review of research on gambling. Psychological Reports. 1993. v. 72, p. 791-810. 